\title{
Evaluation of the WHO criteria for the classification of patients with mastocytosis
}

Laura Sánchez-Muñoz ${ }^{1}$, Ivan Alvarez-Twose ${ }^{1}$, Andrés C García-Montero², Cristina Teodosio ${ }^{2}$, María Jara-Acevedo ${ }^{2}$, Carlos E Pedreira ${ }^{3}$, Almudena Matito ${ }^{1}$, Jose Mario T Morgado ${ }^{1}$, Maria Luz Sánchez ${ }^{2}$, Manuela Mollejo ${ }^{4}$, David Gonzalez-de-Olano ${ }^{5}$, Alberto Orfao ${ }^{2}$ and Luis Escribano ${ }^{1}$

${ }^{1}$ Instituto de Estudios de Mastocitosis de Castilla La Mancha, Hospital Virgen del Valle, Toledo, Spain; ${ }^{2}$ Servicio General de Citometría, Instituto de Biología Molecular y Celular del Cáncer, Centro de Investigación del Cáncer/IBMCC (CSIC-USAL) and Departamento de Medicina, Universidad de Salamanca, Salamanca, Spain; ${ }^{3}$ Faculty of Medicine and COPPE, Engineering Graduate Program, UFRJ/Federal University of Rio de Janeiro, Rio de Janeiro, Brazil; ${ }^{4}$ Servicio de Anatomía Patológica, Hospital Virgen de la Salud, Toledo, Spain and ${ }^{5}$ Servicio de Alergología, Hospital de Fuenlabrada, Madrid, Spain

\begin{abstract}
Diagnosis and classification of mastocytosis is currently based on the World Health Organization (WHO) criteria. Here, we evaluate the utility of the WHO criteria for the diagnosis and classification of a large series of mastocytosis patients $(n=133)$, and propose a new algorithm that could be routinely applied for refined diagnosis and classification of the disease. Our results confirm the utility of the WHO criteria and provide evidence for the need of additional information for (1) a more precise diagnosis of mastocytosis, (2) specific identification of new forms of the disease, (3) the differential diagnosis between cutaneous mastocytosis vs systemic mastocytosis, and (4) improved distinction between indolent systemic mastocytosis and aggressive systemic mastocytosis. Based on our results, a new algorithm is proposed for a better diagnostic definition and prognostic classification of mastocytosis, as confirmed prospectively in an independent validation series of 117 mastocytosis patients.
\end{abstract}

Modern Pathology (2011) 24, 1157-1168; doi:10.1038/modpathol.2011.84; published online 6 May 2011

Keywords: diagnosis; mastocytosis; WHO classification

During the last two decades, major advances have been achieved in the diagnosis and classification of mastocytosis. In 1991, a comprehensive clinicomorphological classification identified two major categories of mastocytosis associated with good and poor prognosis, respectively; noteworthy, indolent systemic mastocytosis without skin lesions was included in this classification as a clinical entity. ${ }^{1}$ Ten years later, an updated consensus classification of mastocytosis was proposed by the World Health Organization (WHO) ${ }^{2-4}$ in which, in addition to major conventional histopathological criterion (multifocal dense aggregates of $\geq 15$ mast cells in bone

Correspondence: Dr L Escribano, MD, PhD, FAAAAI, Instituto de Estudios de Mastocitosis de Castilla La-Mancha, Hospital Virgen del Valle, Carretera Cobisa, s/n., Toledo 45071, Spain.

E-mail: sanchezlaura99@gmail.com

Received 18 February 2011; revised and accepted 30 March 2011; published online 6 May 2011 marrow and/or other extracutaneous tissues), four minor morphological (atypical mast cells in smears or biopsy sections of bone marrow or other extracutaneous organs), immunophenotypical (CD25 ${ }^{+}$ and/or $\mathrm{CD}^{+}$mast cells), molecular (D816V KIT mutation) and biochemical (serum tryptase levels persistently $>20 \mathrm{ng} / \mathrm{ml}$ ) criteria are recommended for the diagnosis of systemic mastocytosis. According to the WHO, additional clinical investigations should be performed to define the exact subtype of the disease. Overall, seven categories of mastocytosis are defined in the WHO classification: cutaneous mastocytosis, extracutaneous mastocytoma, indolent systemic mastocytosis, aggressive systemic mastocytosis, systemic mastocytosis associated with other clonal hematological non-mast cell lineage disease, mast cell leukemia, and mast cell sarcoma.

More recently, diagnostic guidelines, algorithms, and recommendations to facilitate implementation of the WHO criteria have been proposed and 
preliminary descriptions of new provisional subvariants have been described; $;^{5-12}$ these include well-differentiated systemic mastocytosis ${ }^{13,14}$ and clonal mast cell-activation syndromes in the absence of skin lesions, also termed as monoclonal mast cell-activation syndrome ${ }^{12,15}$ or clonal mast cell-activation disorders, ${ }^{16,17}$ the later only partially fulfilling the criteria for systemic mastocytosis.

Overall, the great majority of mastocytosis cases belong to the good-prognosis categories of the disease (eg cutaneous mastocytosis, indolent systemic mastocytosis, and well-differentiated systemic mastocytosis) and they are typically characterized by low mast cell burden, particularly at early stages of the disease. However, recent results suggest that these categories remain heterogeneous and some patients experience disease progression, particularly those with elevated serum $\beta_{2}$-microglobulin levels and D816V KIT mutation involving multiple myeloid or myeloid plus lymphoid hematopoietic lineages. ${ }^{18}$ These results indicate that refined criteria for an improved prognostic stratification of systemic mastocytosis are needed, particularly for cases at early phases of the disease.

Despite all the above, so far the utility of the WHO classification for the diagnosis and classification of mastocytosis has been prospectively evaluated in only one study, which suggests that the WHO criteria for systemic mastocytosis may still be associated with some false-negative cases. ${ }^{19}$ A total of 59 patients with clinically suspected systemic mastocytosis, underwent comprehensive evaluation and 53 of them (90\%) met the diagnostic criteria for systemic mastocytosis. In the six patients in which bone marrow examination could not confirm systemic mastocytosis, atypical mast cell morphology was identified in five, aberrant immunophenotype in five, KIT mutation in two, and elevated serum tryptase in two. None of these cases met the major criteria; one of the patients had systemic mastocytosis of the spleen. The results showed the relative values of traditional morphologic criteria (ie major criterion) and the results of ancillary testing (ie minor criteria), suggesting that the WHO system is neither completely sensitive nor specific for systemic mastocytosis. ${ }^{19}$

Here, we prospectively evaluate the utility of different clinical, biological, immunophenotypical, and molecular features of the disease (including all WHO major and minor diagnostic criteria), in a cohort of 133 patients uniformly diagnosed and followed at the Spanish Network on Mastocytosis (REMA). Based on our findings, a new algorithm is proposed, which may contribute to improve refined diagnosis and classification of mastocytosis. Accordingly, the proposed refined classification of mastocytosis provides better diagnosis and longterm prognosis classification of mastocytosis, as confirmed prospectively in an independent validation series of 117 mastocytosis patients.

\section{Patients and methods}

\section{Patients and Controls}

A total of 250 patients with suspected mastocytosis were studied. These included 133 patients-69 women and 64 men; median age of 42 years, range: 9-77 years-who were consecutively referred to the Instituto de Mastocitosis de Castilla La Mancha (CLMast) (Reference Centre of the Spanish Network on Mastocytosis; REMA) from January 1996 till September 2007 (Test group), plus 117 patients (68 women and 49 men; mean age of 44 years, range: $21-71$ years), who were consecutively referred to the same center (CLMast) from September 2007 to December 2009 (Validation group). None of them had received cytoreductive therapy before inclusion in the study.

A control group of 855 bone marrow samples from either healthy subjects $(n=57 ; 7 \%)$ or patients with different hematological and non-hematological disorders $(n=798 ; 93 \%)$ other than mastocytosis (Table 1)-median age of 69 years (range: 17-93 years)—was analyzed in parallel. All participants gave their written informed consent to participate in the study, and the study was approved by the Hospital's Ethics Committee.

\section{Diagnostic Work-Up for Mastocytosis}

All mastocytosis patients had a complete physical examination, blood cell count and differential,

Table 1 Control subjects: distribution of healthy subjects and control patients included in this study according to diagnosis

\begin{tabular}{lc}
\hline Diagnosis & No. of cases \\
\hline Healthy controls & $57(7 \%)$ \\
Patients with lymphoid neoplasias & $448(52 \%)$ \\
Acute lymphoblastic leukemia & 15 \\
Chronic lymphocytic leukemia & 74 \\
Hodgkin lymphoma & 25 \\
Non-Hodgkin's lymphoma & 159 \\
Waldenström's macroglobulinemia & 23 \\
Multiple myeloma & 87 \\
Plasma cell leukemia & 2 \\
Monoclonal gammopathy of undetermined & 63 \\
significance & \\
Patients with myeloid malignancies & $142(17 \%)$ \\
Acute myeloid leukemia & 33 \\
Chronic myeloid leukemia & 39 \\
Myelodysplastic syndrome & 45 \\
Myeloproliferative disorders & 25 \\
Patients with other non-neoplastic diseases & $113(13 \%)$ \\
Anemia & 42 \\
Hypocellular bone marrow & 36 \\
Immune thrombocytopenic purpura & 6 \\
Polyclonal lymphocytosis & 15 \\
Hypereosinophilia/chronic eosinophilic leukemia & 14 \\
Individuals with other disease conditions & $95(11 \%)$ \\
Anaphylaxis & 15 \\
Reactive bone marrow & 53 \\
Solid tumor & 27 \\
Total & $855(100 \%)$ \\
\end{tabular}


routine serum biochemistry tests, abdominal ultrasonography and/or computed tomography-scan, dual energy X-ray absorptiometry, and skeletal X-ray survey. Presence of osteoporosis was defined following well-established criteria ${ }^{20,21}$ and the presence of bone sclerosis-as assessed by skeletal X-ray survey and/or computed tomography-scanwas also recorded. Skin biopsy was performed in all cases with cutaneous lesions. Serum tryptase (CAP, Phadia, Uppsala, Sweden) was measured in all patients at the time of bone marrow biopsy.

Bone marrow evaluation was performed following previously established criteria for morphology, ${ }^{6}$ histopathology, immunohistochemistry, ${ }^{5,22,23}$ flow cytometry immunophenotyping, ${ }^{11,24,25}$ detection of KIT mutations, ${ }^{26,27}$ and bone marrow mast cell clonality as previously reported in detail.

For morphological evaluation, bone marrow smears were stained with Wright-Giemsa and toluidine blue and analyzed by three independent pathologists using light microscopy. In each case, 25-100 mast cells were analyzed and classified as described elsewhere. ${ }^{6}$ In addition, the presence of mast cells aggregates in bone marrow particles (as assessed in toluidine blue-stained samples), presence of focal or diffuse eosinophilia, as well as dysplastic features, were also examined and recorded.

Bone marrow biopsy sections were stained with hematoxylin-eosin, giemsa, tryptase, and c-kit stains, and analyzed by three independent pathologists for overall cellularity, mast cell number and morphology, presence of compact mast cells aggregates, grade and type of mast cell infiltration, presence of fibrosis and/or bone sclerosis, and of lymphoid aggregates.

Immunophenotypical analysis of bone marrow mast cells was performed following the REMA guidelines. ${ }^{11,24,25}$ Both external and internal quality controls were routinely applied and all bone marrow samples were studied in parallel at two different laboratories of the REMA. Briefly, bone marrow samples were analyzed by direct immunofluorescence using $\geq 3$ color flow cytometer, after staining of bone marrow cells with fluorochrome-conjugated monoclonal antibodies. The CELLQuest PRO (BD Biosciences) and Paint-A-Gate PRO software programs (BD Biosciences) were used for data acquisition and analysis as described elsewhere. ${ }^{11,24,28,29}$

KIT D816V mutation and other KIT mutations localized at codons 814-819 (exon 17) were detected on highly purified ( $\geq 97 \%$ purity) bone marrow cell populations, as previously described. ${ }^{27,30}$ In turn, identification of KIT mutations at exons 2, 9, 10, 11, 13,14 , and 15 was performed on genomic DNA by direct sequencing of the amplified PCR products in both directions, using the dye-deoxy terminator method, in an ABI Prism 3100 Genetic Analyzer (Applied Biosystems, Foster City, CA, USA). To evaluate clonality in female patients without KIT mutation, the pattern of inactivation of chromosome
$\mathrm{X}$ was studied by the human-androgen receptor- $\alpha$ gene (HUMARA) assay. ${ }^{31}$

\section{Statistical Methods}

For all statistical analyses, the SPSS 15.0 software (Chicago, IL, USA) was used. Median values, mean, s.d., and range were calculated for all continuous variables in each group; for categorical variables, frequencies were used. Comparisons between groups were performed with either the non-parametric Kruskal-Wallis and Mann-Whitney $U$-tests (for continuous variables) or the Pearson $\chi^{2}$ and Fisher's exact tests (for categorical variables). $P$-values $<0.05$ were considered to be associated with statistical significance. Receiver operating curves were used to assess the sensitivity and specificity of each variable or combination of variables, for the diagnosis and classification of individual cases.

A hierarchical logical inference procedure was used through intensive computation to build 'diagnostic' algorithms, consisting of a combination of propositions associated by logical operators attaining a web of conjunctions, disjunctions, and conditionals. Briefly, an ensemble of previously diagnosed cases was used by way of inductive learning, to infer a general rule that satisfied all cases.

\section{Results}

\section{WHO Criteria Applied to Controls and Mastocytosis (Test Group)}

None of the 855 control bone marrow samples met the diagnostic criteria for systemic or cutaneous mastocytosis (Table 2). However, six cases fulfilled one $(n=4)$ or two $(n=2)$ minor criteria. These included three cases with morphologically abnormal bone marrow mast cells: two FIP1L1/PDGFRApositive chronic eosinophilic leukemia, also exhibiting CD25 $5^{\text {bright }+}$ bone marrow mast cells and one myelodysplastic syndrome. The remaining three patients corresponded to control cases with increased serum tryptase and recurrent anaphylaxis (severe systemic mast cell-activation syndromes) without other criteria for systemic mastocytosis (non-clonal idiopathic or secondary mast cell-activation syndrome).

Based on the WHO criteria, from the 133 mastocytosis patients of the test group, $20(15 \%)$ were classified as cutaneous mastocytosis and 112 (85\%) as systemic mastocytosis: indolent systemic mastocytosis, 93 (70\%), aggressive systemic mastocytosis, $11(8 \%)$, systemic mastocytosis associated with other clonal hematological non-mast cell lineage disease, 6 (5\%), and mast cell leukemia, 2 (1\%); one case was unclassifiable (Table 2). This later patient was referred because of anaphylaxis episodes and he had neither skin lesions nor bone marrow mast cell 
Table 2 Distribution of mastocytosis patients and controls according to the WHO diagnostic criteria

\begin{tabular}{|c|c|c|c|c|c|c|}
\hline $\begin{array}{l}\text { WHO subtype of } \\
\text { mastocytosis }\end{array}$ & $\begin{array}{c}\text { No. of } \\
\text { cases }(\%)\end{array}$ & $\begin{array}{l}\text { Compact bone } \\
\text { marrow mast cell } \\
\text { aggregates }\end{array}$ & $\begin{array}{l}\text { Morphologically } \\
\text { atypical bone } \\
\text { marrow mast cell }\end{array}$ & $\begin{array}{c}C D 25^{+} \text {and/or } C D 2^{+} \\
\text {bone marrow mast } \\
\text { cell }\end{array}$ & $\begin{array}{l}\text { KIT D816 } V^{+} \\
\text {bone marrow } \\
\text { mast cell }\end{array}$ & $\begin{array}{l}\text { Serum tryptase } \\
\quad>20 \mathrm{ng} / \mathrm{ml}\end{array}$ \\
\hline Total mastocytosis & 133 & 100/133 (75\%) & 107/133 (80\%) & 115/133 (86\%) & 108/133 (81\%) & $83 / 133(62 \%)$ \\
\hline Cutaneous mastocytosis & $20(15 \%)$ & $30 \%$ & $5 \%$ & $20 \%$ & $10 \%$ & $0 \%$ \\
\hline $\begin{array}{l}\text { Indolent systemic } \\
\text { mastocytosis }\end{array}$ & $93(70 \%)$ & $81 \%$ & $95 \%$ & $98 \%$ & $92 \%$ & $72 \%$ \\
\hline $\begin{array}{l}\text { Systemic mastocytosis } \\
\text { associated to an } \\
\text { hematological non-mast } \\
\text { cell disease }\end{array}$ & $6(5 \%)$ & $100 \%$ & $83 \%$ & $100 \%$ & $100 \%$ & $66 \%$ \\
\hline $\begin{array}{l}\text { Aggressive systemic } \\
\text { mastocytosis }\end{array}$ & $11(8 \%)$ & $100 \%$ & $100 \%$ & $100 \%$ & $100 \%$ & $90 \%$ \\
\hline Mast cell leukemia & $2(1 \%)$ & $100 \%$ & $100 \%$ & $100 \%$ & $100 \%$ & $100 \%$ \\
\hline Unclassifiable & $1(1 \%)$ & $0 \%$ & $0 \%$ & $100 \%$ & $100 \%$ & $0 \%$ \\
\hline Controls & 855 & $0 \%$ & $4 \%$ & $1 \%$ & $0 \%$ & $3 \%$ \\
\hline
\end{tabular}

Results are expressed as number of positive cases from all cases analyzed and percentage between brackets.

aggregates; however, he had aberrant CD25 bright+ bone marrow mast cells with the D816V KIT mutation, suggesting it could correspond to an early phase of indolent systemic mastocytosis without skin lesions. The frequency of cases fulfilling the different WHO major and minor criteria for systemic mastocytosis are shown in Table 2 . In detail, dense aggregates of $\geq 15$ bone marrow mast cells were found in all systemic mastocytosis associated with other clonal hematological non-mast cell lineage disease, aggressive systemic mastocytosis, and mast cell leukemia cases, but in only 30 and $81 \%$ of cutaneous mastocytosis and indolent systemic mastocytosis cases, respectively (Table 3). Roundshaped bone marrow mast cells predominated in cutaneous mastocytosis (90\%), while spindle mast cells or a mixed morphology was more frequent in systemic mastocytosis $(P<0.0001$; Table 3). All systemic mastocytosis associated with other clonal hematological non-mast cell lineage disease, aggressive systemic mastocytosis, and mast cell leukemia cases and most (98\%) indolent systemic mastocytosis patients showed CD25 $5^{\text {bright }}+$ bone marrow mast cells (Table 2). Noteworthy, expression of CD25 $5^{\text {bright }+}$ was also detected on bone marrow mast cells from $4 / 20(20 \%)$ cutaneous mastocytosis and the unclassifiable case. Eighty percent of systemic mastocytosis cases also coexpressed CD2 on bone marrow mast cells: 73/93 indolent systemic mastocytosis $(78 \%), 5 / 6$ systemic mastocytosis associated with other clonal hematological non-mast cell lineage disease (83\%), 9/10 aggressive systemic mastocytosis (90\%), and 0/1 mast cell leukemia (Table 2). Most patients with mastocytosis $(n=108 / 133 ; 81 \%)$ carried the D816V KIT mutation in bone marrow mast cells: $10 \%$ of cutaneous mastocytosis, $92 \%$ of indolent systemic mastocytosis, and all (100\%) systemic mastocytosis associated with other clonal hematological non-mast cell lineage disease, aggressive systemic mastocytosis, and mast cell leukemia patients (Table 2). Of note, the two KIT mutationpositive cutaneous mastocytosis cases also showed CD2 $5^{\text {bright }+}$ bone marrow mast cells. Serum tryptase $>20 \mathrm{ng} / \mathrm{ml}$ was detected in $72 \%$ of indolent systemic mastocytosis cases (median: $27.1 \mathrm{ng} / \mathrm{ml}$ ). All patients in the aggressive groups had highly elevated serum tryptase-median of $195 \mathrm{ng} / \mathrm{ml}$ for aggressive systemic mastocytosis $(P<0.0001$ vs indolent systemic mastocytosis) and $587 \mathrm{ng} / \mathrm{ml}$ for mast cell leukemia $(P<0.001$ vs indolent systemic mastocytosis)—except for one aggressive systemic mastocytosis patient who showed normal serum tryptase levels and was classified as aggressive systemic mastocytosis because of the presence of organomegalies with organ failure, malabsorption, and cytopenias. 'C'-findings were found in $10 \%$ of mastocytosis patients including skeletal involvement $(4 \%)$, bone marrow dysfunction with cytopenia(s) $(7.5 \%)$, and malabsorption with weight loss $(3 \%)$. Hepatosplenomegaly with or without signs of organ failure was found in 4 and $17 \%$ of the cases, respectively (the former was seen in $4 / 11$ (36\%) aggressive systemic mastocytosis and $2 / 2$ mast cell leukemia cases). In all systemic mastocytosis associated with other clonal hematological non-mast cell lineage disease cases, the specific subtype of mastocytosis corresponded to an indolent systemic mastocytosis and the associated hematological diseases were myelodisplastic syndrome $(n=1)$, acute myeloid leukemia $(n=1)$, non-Hodgkin's lymphoma $(n=1)$, polycythemia vera $(n=2)$, and essential thrombocythemia $(n=1)$.

\section{Differential Diagnosis of Cutaneous vs Systemic Mastocytosis}

Among those 20 patients classified as cutaneous mastocytosis by the WHO, three different subgroups were identified (Table 4). The first subgroup was 
Table 3 Cytomorphological and histopathological characteristics of bone marrow samples from mastocytosis patients grouped according to the WHO subtype of the disease vs controls

(A) Cytomorphological characteristics

\begin{tabular}{|c|c|c|c|c|c|}
\hline WHO subtype of mastocytosis & $\begin{array}{l}\text { Increased } \\
\text { mast cells }\end{array}$ & $\begin{array}{l}\text { Round; spindle; } \\
\text { mixed }^{*} \text { mast cells }\end{array}$ & $\begin{array}{l}\text { Mast cell } \\
\text { aggregates }\end{array}$ & Eosinophilia & Promastocytes \\
\hline Mastocytosis & $114 / 133(86 \%)$ & $25 ; 45 ; 63$ & $100 / 128(78 \%)$ & 49/133 (37\%) & $32 / 133(24 \%)$ \\
\hline Cutaneous mastocytosis & $10 / 20(50 \%)$ & $18 ; 1 ; 1$ & $8 / 20(44 \%)$ & $4 / 20(20 \%)$ & $0 / 20(0 \%)$ \\
\hline Indolent systemic mastocytosis & $85 / 93(91 \%)$ & $4 ; 38 ; 51$ & $74 / 91(81 \%)$ & $38 / 93(41 \%)$ & $24 / 93(26 \%)$ \\
\hline $\begin{array}{l}\text { Systemic mastocytosis associated to an } \\
\text { hematological non-mast cell disease }\end{array}$ & $6 / 6(100 \%)$ & $1 ; 1 ; 4$ & $6 / 6(100 \%)$ & $1 / 6(17 \%)$ & $1 / 6(17 \%)$ \\
\hline Aggressive systemic mastocytosis & $11 / 11(100 \%)$ & $0 ; 4 ; 7$ & $11 / 11(100 \%)$ & $5 / 11(45 \%)$ & $5 / 11(45 \%)$ \\
\hline Mast cell leukemia & $2 / 2(100 \%)$ & $1 ; 1 ; 0$ & $2 / 2(100 \%)$ & $0 / 2(0 \%)$ & $2 / 2(100 \%)$ \\
\hline Unclassifiable & $0 / 1(0 \%)$ & $1 ; 0 ; 0$ & $0 / 1(0 \%)$ & $1 / 1(100 \%)$ & $0 / 1(0 \%)$ \\
\hline Controls & $83 / 83(100 \%)$ & $27 ; 3 ; 53$ & $6 / 83(7 \%)$ & $14 / 83(17 \%)$ & $0 / 83(0 \%)$ \\
\hline
\end{tabular}

(B) Histopathological characteristics

\begin{tabular}{|c|c|c|c|c|c|}
\hline WHO subtype of mastocytosis & $\begin{array}{l}\text { Compact mast } \\
\text { cell aggregates }\end{array}$ & $\begin{array}{l}\text { Subdiagnostic mast } \\
\text { cell aggregates }\end{array}$ & $\begin{array}{l}\text { Bone marrow } \\
\text { fibrosis }\end{array}$ & $\begin{array}{l}\text { Bone marrow } \\
\text { sclerosis }\end{array}$ & $\begin{array}{l}\text { Lymphoid } \\
\text { aggregates }\end{array}$ \\
\hline Mastocytosis & $100 / 133(75 \%)$ & $12 / 32(37 \%)$ & $46 / 132(35 \%)$ & $18 / 132(14 \%)$ & $58 / 131(44 \%)$ \\
\hline Cutaneous mastocytosis & $6 / 20(30 \%)$ & $1 / 14(7 \%)$ & $0 / 20(0 \%)$ & $0 / 20(0 \%)$ & $3 / 20(15 \%)$ \\
\hline Indolent systemic mastocytosis & $75 / 93(81 \%)$ & $11 / 17(65 \%)$ & $29 / 92(31 \%)$ & $11 / 92(12 \%)$ & $48 / 91(53 \%)$ \\
\hline $\begin{array}{l}\text { Systemic mastocytosis associated to an } \\
\text { hematological non-mast cell disease }\end{array}$ & $6 / 6(100 \%)$ & $0 / 1(0 \%)$ & $5 / 6(83 \%)$ & $0 / 6(0 \%)$ & $3 / 6(50 \%)$ \\
\hline Aggressive systemic mastocytosis & $11 / 11(100 \%)$ & NA & $11 / 11(100 \%)$ & $7 / 11(64 \%)$ & $4 / 11(36 \%)$ \\
\hline Mast cell leukemia & $2 / 2(100 \%)$ & NA & $1 / 2(50 \%)$ & $0 / 2(0 \%)$ & $0 / 2(0 \%)$ \\
\hline Unclassifiable & $0 / 1(0 \%)$ & $0 / 1(0 \%)$ & $0 / 1(0 \%)$ & $0 / 1(0 \%)$ & $0 / 1(0 \%)$ \\
\hline Controls & $0 / 46(0 \%)$ & $1 / 46(2 \%)$ & $1 / 46(2 \%)$ & $1 / 46(2 \%)$ & $9 / 46(20 \%)$ \\
\hline
\end{tabular}

NA: not applied.

Results are expressed as number of positive cases/from all cases analyzed and percentage between brackets or as *number of cases.

composed of patients with only mastocytosis in the skin but no major or minor criteria for systemic mastocytosis $-n=9 ; 8$ women $(89 \%)$. The second subgroup, included six patients with mastocytosis in the skin associated with 'tryptase-positive round cell infiltration of bone marrow' ${ }^{32}$ (TROCI) by c-kit + round-shaped and fully granulated mast cells with a mature CD25-/CD2 ${ }^{-}$phenotype $^{33}$ in the absence of D816V KIT mutation. Although these cases fulfilled only the major WHO diagnostic criterion for systemic mastocitosis, they all showed typical clinical, cytogenetic, and molecular features of well-differentiated systemic mastocytosis. ${ }^{13,14}$ Finally, the third subgroup consisted of five patients with mastocytosis in the skin, no major diagnostic criterion for systemic mastocytosis but the presence of either 1 or 2 minor criteria; 4/5 cases had a low bone marrow mast cell burden with normal serum baseline tryptase and coexistence of a double population of clonal CD25 bright+ and polyclonal CD25- mast cells and either the D816V KIT mutation $(n=2)$ or morphologically atypical bone marrow mast cell $(n=1)$, suggesting that these cases could correspond to early stages of indolent systemic mastocytosis; the fifth case presented with mastocytosis in the skin and clonal bone marrow mast cell together with round-shaped mast cells, suggesting well-differentiated systemic mastocytosis with low bone marrow mast cell burden.

\section{Classification of Systemic Mastocytosis}

Among indolent systemic mastocytosis cases as per the WHO, three subgroups of patients could be clearly distinguished; two major groups identified by the presence $(n=77$; indolent systemic mastocytosis with skin lesions) vs absence $(n=16$; indolent systemic mastocytosis without skin lesions) of mastocytosis in the skin. And a small group identified by the presence of the so-called 'tryptase-positive round cell infiltration of bone marrow' (compact tryptase-positive round cell infiltrates of the bone marrow), c-kit + round-shaped and fully granulated mast cells displaying a mature $\mathrm{CD} 25^{-} / \mathrm{CD} 2^{-}$phenotype. The two cases in this later group showed features compatible with well-differentiated systemic mastocytosis; one was associated with the D816V KIT mutation and the other patient showed serum baseline tryptase $>20 \mathrm{ng} / \mathrm{ml}$.

Among the two major groups of indolent systemic mastocytosis (with and without skin lesions), the frequency of diagnostic criteria was similar, except for the presence of clonal bone marrow mast cells (96\% for indolent systemic mastocytosis with skin lesions vs $\mathbf{8 8 \%}$ for indolent systemic mastocytosis without skin lesions, $P=0.16)$ and of dense bone marrow mast cell aggregates $(78 \%$ in indolent systemic mastocytosis with skin lesions, $71 \%$ in indolent systemic mastocytosis without skin 
Table 4 Characteristics of patients classified as cutaneous mastocytosis by the WHO criteria

\begin{tabular}{|c|c|c|c|c|c|c|c|c|c|}
\hline $\begin{array}{l}\text { Subgroups of cutaneous } \\
\text { mastocytosis }\end{array}$ & $\begin{array}{l}\text { No. of } \\
\text { cases }\end{array}$ & $\begin{array}{l}\text { Skin } \\
\text { lesions }\end{array}$ & Anaphylaxis & $\begin{array}{l}\text { Compact bone } \\
\text { marrow } \\
\text { aggregates }\end{array}$ & $\begin{array}{l}\text { Morphologically } \\
\text { atypical bone } \\
\text { marrow mast cells }\end{array}$ & $\begin{array}{l}\text { CD25 } 5^{++} \text {bone } \\
\text { marrow mast } \\
\text { cells }\end{array}$ & $\begin{array}{l}\text { Clonal bone } \\
\text { marrow mast } \\
\text { cells }^{\mathrm{a}}\end{array}$ & $\begin{array}{l}\text { Serum } \\
\text { tryptase } \\
>20 \mu \mathrm{g} / \mathrm{l}\end{array}$ & $\begin{array}{l}\text { Diagnosis according to the } \\
\text { new algorithm (Figure 1) }\end{array}$ \\
\hline $\begin{array}{l}\text { No criteria for systemic } \\
\text { mastocytosis }\end{array}$ & 9 & $9 / 9$ & $1 / 9$ & $0 / 9$ & $0 / 9$ & $0 / 9$ & $0 / 9$ & $0 / 9$ & Cutaneous mastocytosis \\
\hline Major criterion only & 6 & $6 / 6$ & $1 / 6$ & $6 / 6$ & $0 / 6$ & $0 / 6$ & $0 / 6$ & $0 / 6$ & $\begin{array}{l}\text { Well-differentiated systemic } \\
\text { mastocytosis }\end{array}$ \\
\hline 1-2 minor criteria only & 5 & $5 / 5$ & $2 / 5$ & $0 / 5$ & $1 / 5$ & $4 / 5$ & $3 / 5$ & $0 / 5$ & $\begin{array}{l}\text { Indolent systemic } \\
\text { mastocytosis or well- } \\
\text { differentiated systemic } \\
\text { mastocytosis }\end{array}$ \\
\hline Total cutaneous mastocytosis & 20 & $20 / 20$ & $4 / 20$ & $6 / 20$ & $1 / 20$ & $4 / 20$ & $3 / 20$ & $0 / 20$ & \\
\hline
\end{tabular}

Results are expressed as number of positive cases from all cases analyzed.

${ }^{\mathrm{a}}$ Clonal bone marrow mast cells: including all KIT mutations other than D816V or a clonal HUMARA test.

Table 5 Distribution of mastocytosis patients $(n=133)$ according to the newly proposed algorithm for the diagnosis and classification of mastocytosis (Figure 1)

\begin{tabular}{|c|c|c|c|c|c|c|c|}
\hline Subtype of mastocytosis & $\begin{array}{l}\text { No. of cases } \\
(\%)\end{array}$ & $\begin{array}{l}\text { Skin } \\
\text { lesions }\end{array}$ & Anaphylaxis & $\begin{array}{l}\text { CD25 } 5^{++} \text {bone } \\
\text { marrow } \\
\text { mast cells }\end{array}$ & $\begin{array}{l}\text { Clonal bone } \\
\text { marrow mast } \\
\text { cells }^{\mathrm{a}}\end{array}$ & $\begin{array}{l}\text { Compact bone } \\
\text { marrow mast } \\
\text { cell aggregates }\end{array}$ & $\begin{array}{l}\text { Morphologically } \\
\text { atypical bone } \\
\text { marrow mast } \\
\text { cells }\end{array}$ \\
\hline Cutaneous mastocytosis & $9 / 133(7 \%)$ & $9 / 9$ & $1 / 9$ & $0 / 9$ & $0 / 9$ & $0 / 9$ & $0 / 9$ \\
\hline $\begin{array}{l}\text { Well-differentiated systemic } \\
\text { mastocytosis }\end{array}$ & $9 / 133(7 \%)$ & $9 / 9$ & $1 / 9$ & $0 / 9$ & $7 / 9$ & $8 / 9$ & $0 / 9$ \\
\hline $\begin{array}{l}\text { Indolent systemic mastocytosis } \\
\text { with skin lesions }\end{array}$ & $82 / 133(61 \%)$ & $82 / 82$ & $14 / 82$ & $82 / 82$ & $79 / 82$ & $64 / 82$ & $76 / 82$ \\
\hline $\begin{array}{l}\text { Indolent systemic mastocytosis } \\
\text { without skin lesions }\end{array}$ & $17 / 133(13 \%)$ & $0 / 17$ & $17 / 17$ & $17 / 17$ & $15 / 17$ & $12 / 17$ & $16 / 17$ \\
\hline $\begin{array}{l}\text { Systemic mastocytosis associated to } \\
\text { other hematological non-mast cell } \\
\text { lineage disease }\end{array}$ & $6 / 133(4.5 \%)$ & $3 / 6$ & $1 / 6$ & $6 / 6$ & $6 / 6$ & $6 / 6$ & $5 / 6$ \\
\hline Aggressive systemic mastocytosis & $8 / 133(6 \%)$ & $6 / 8$ & $3 / 8$ & $8 / 8$ & $8 / 8$ & $8 / 8$ & $8 / 8$ \\
\hline Mast cell leukemia & $2 / 133(1.5 \%)$ & $0 / 2$ & $0 / 2$ & $2 / 2$ & $2 / 2$ & $2 / 2$ & $2 / 2$ \\
\hline Total & 133 & $109 / 133(82 \%)$ & $37 / 133(27.8 \%)$ & 115/133 (86.5\%) & $\begin{array}{l}117 / 133 \\
(94.4 \%)\end{array}$ & $\begin{array}{l}100 / 133 \\
(75.2 \%)\end{array}$ & $107 / 133(80 \%)$ \\
\hline
\end{tabular}

Results are expressed as number of positive cases from all cases analyzed and percentage between brackets, or just as number of positive cases from all cases analyzed.

${ }^{\mathrm{a}}$ Clonal bone marrow mast cells: including all KIT mutations other than D816V or a clonal result in a HUMARA test in females. 
Table 6 Distribution of mastocytosis patients according to $\beta_{2}$-microglobulin and LDH serum levels

\begin{tabular}{|c|c|c|c|}
\hline Subtype of mastocytosis ${ }^{\mathrm{a}}$ & $\begin{array}{l}\text { Increased serum } \\
\beta_{2} \text {-microglobulin }\end{array}$ & $\begin{array}{l}\text { Decreased } \\
\text { serum } L D H\end{array}$ & $\begin{array}{c}\text { Increased serum } \\
\beta_{2} \text {-microglobulin and } \\
\text { decreased serum } \mathrm{LDH}\end{array}$ \\
\hline Cutaneous mastocytosis & $0 / 9$ & $0 / 9$ & $0 / 9$ \\
\hline Well-differentiated systemic mastocytosis & $0 / 9$ & $2 / 9$ & $0 / 9$ \\
\hline Indolent systemic mastocytosis (with skin lesions) & $8 / 82$ & $15 / 82$ & $2 / 82$ \\
\hline Indolent systemic mastocytosis (without skin lesions) & $1 / 17$ & $2 / 17$ & $0 / 17$ \\
\hline $\begin{array}{l}\text { Systemic mastocytosis associated to other hematological } \\
\text { non-mast cell disease }\end{array}$ & $2 / 6$ & $1 / 6$ & $0 / 6$ \\
\hline Aggressive systemic mastocytosis & $7 / 8$ & $7 / 8$ & $7 / 8$ \\
\hline Mast cell leukemia & $2 / 2$ & $2 / 2$ & $2 / 2$ \\
\hline
\end{tabular}

LDH: lactic acid dehydrogenase.

Results are expressed as number of positive cases from all cases analyzed and percentage between brackets.

${ }^{\mathrm{a}}$ Cases were classified according to the algorithm proposed in Figure 1.

lesions, $P=0.51$ ) (Table 5). A more detailed analysis of the clinical symptoms of both groups of patients showed a higher frequency of both mast cell mediators release-associated symptoms in between the acute episodes and KIT mutation restricted to mast cells, among indolent systemic mastocytosis without skin lesions vs indolent systemic mastocytosis with skin lesions (56 vs $24 \%$ and 82 vs $76 \%$, $P=0.003$ and $P=0.071$, respectively) (Table 5).

Regarding aggressive systemic mastocytosis, 8 of 11 patients, classified as such by the WHO criteria, had aggressive disease with C-findings in the absence of pathologic fractures. Most interestingly, all but one of these eight aggressive systemic mastocytosis patients, showed increased $\beta_{2}$-microglobulin in association with decreased LDH serum levels, both parameters being found in only a minority of all indolent systemic mastocytosis, with skin lesions and other indolent forms of the disease $(2 / 105 ; 2 \%)$ (Table 6). Conversely, the other three aggressive systemic mastocytosis cases as per the WHO, had stable disease and they were placed in this category only because of the presence of skeletal lesions in the absence of other clinical findings of aggressiveness (C-findings); in these three patients, vertebral osteoporotic fractures appeared 18,8 , and 5 years after the onset of aggressive systemic mastocytosis after a follow-up of 39, 34, and 15 years from disease onset, respectively. Among these three cases, disease progression was found in one of them, with KIT mutation involving mast cells and both myeloid and lymphoid lineages, 38 years after the onset. Noteworthy, all the three cases showed normal $\beta_{2}$-microglobulin and LDH serum levels.

\section{Proposed Algorithm for Refined Diagnosis and Classification of Mastocytosis}

Based on the above findings, a new algorithm for refined diagnosis and classification of mastocytosis was developed (Figure 1). Through this algorithm, patients without mastocytosis could be easily identified because of the systematic absence of both:
(1) skin lesions and (2) KIT mutation or clonal bone marrow mast cells, if at least, (3) one of the following additional criteria is present at diagnosis: (1) absence of anaphylaxis; (2) normal bone marrow mast cell immunophenotype; (3) absence of compact bone marrow mast cell aggregates; or (4) cytomorphologically normal bone marrow mast cells (Figure 1). Among mastocytosis, cutaneous mastocytosis is defined by the absence of (1) KIT mutation/clonal bone marrow mast cells and (2) compact mast cell aggregates in the bone marrow, with (3) a normal bone marrow mast cell immunophenotype (Figure 1). In turn, systemic mastocytosis cases systematically had CD25 $5^{\text {bright }+}$ bone marrow mast cells and/or compact bone marrow mast cell aggregates in the bone marrow biopsy (Figure 1).

Among systemic mastocytosis, well-differentiated systemic mastocytosis could be identified and discriminated from other disease subtypes because of coexisting skin lesions-usually nodular or plaque form (data not shown), compact bone marrow aggregates, and a mature bone marrow mast cell immunophenotype, typically in the absence of the KIT D816V mutation (Figure 1). In turn, indolent systemic mastocytosis without skin lesions, patients were characterized by the absence of mastocytosis in the skin in association with severe systemic mast cell mediator-related symptoms (eg anaphylaxis) (mast cell-activation syndrome) and low mast cell burden $(<10 \%$ clonal bone marrow mast cells by flow cytometry and $<30 \%$ bone marrow mast cell infiltration by histopathology) (Figure 1). Mast cell leukemia displayed a high bone marrow mast cell burden $(>10 \%$ of marrow mast cell by flow cytometry and/or $>30 \%$ bone marrow mast cell by histopathology) usually in the absence of mastocytosis in the skin (Figure 1; Table 5). Finally, coexistence of CD25 $5^{\text {bright }+}$ and compact bone marrow mast cell aggregates identified indolent systemic mastocytosis with skin lesions and aggressive systemic mastocytosis patients, in addition to systemic mastocytosis associated with other clonal hematological non-mast cell lineage disease cases. Distinction between indolent systemic mastocytosis 


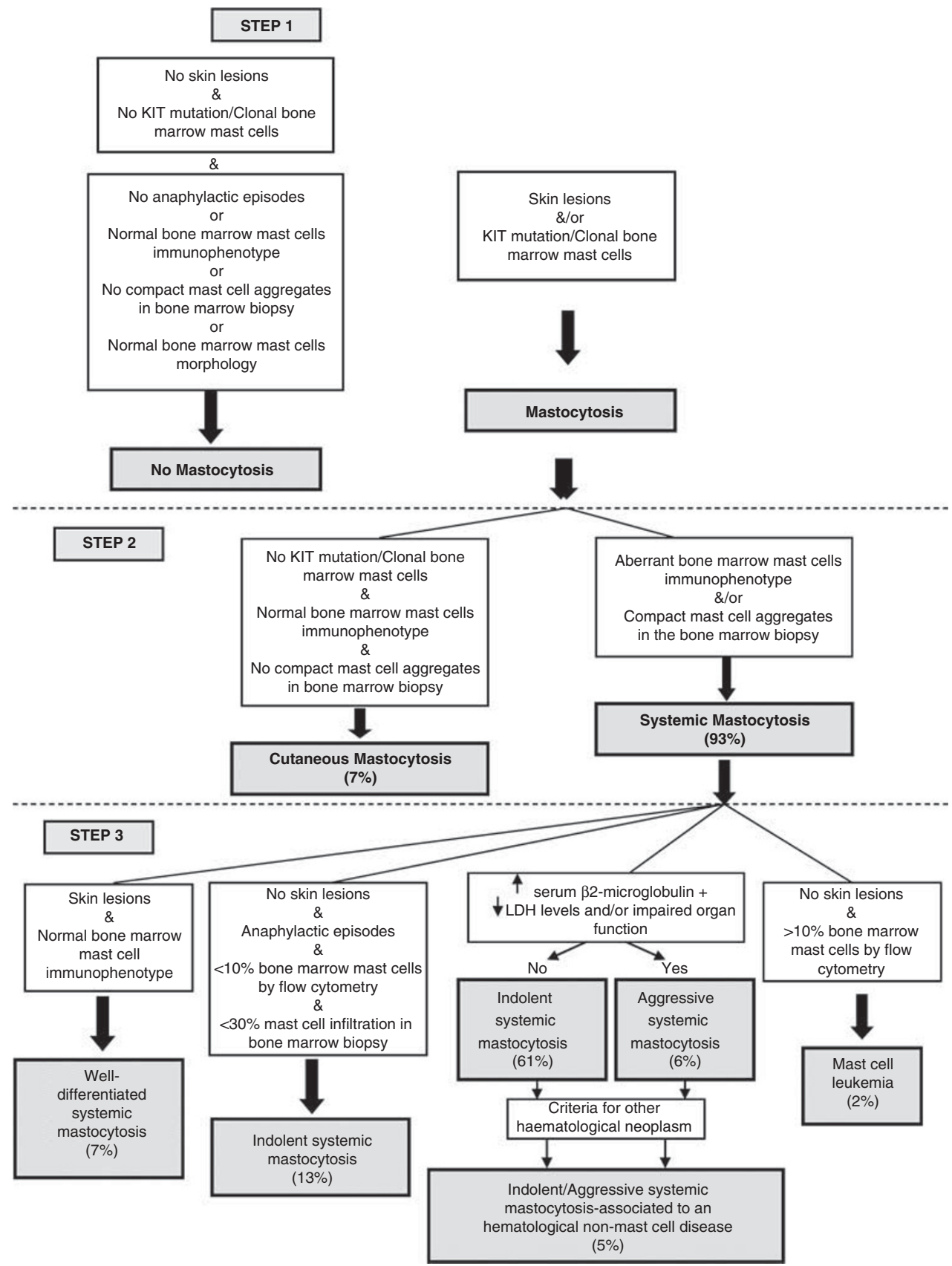

Figure 1 Proposed REMA algorithm for the diagnosis and classification of different subtypes of mastocytosis. The specific percentage of mastocytosis patients $(n=133)$ included in each category is shown between brackets.

and aggressive systemic mastocytosis required further WHO criteria such as C-findings (ie bone marrow organ dysfunction with cytopenias, organomegaly with organ failure, and severe malabsorption with hypoalbuminemia and weight loss, and large sized osteolysis with local mast cell infiltration), typically associated with increased $\beta_{2}$-microglobulin and decreased LDH serum levels in the later patients (ie aggressive systemic mastocytosis) (Table 6). In turn, specific diagnosis of systemic mastocytosis associated with other clonal hematological non-mast cell lineage disease cases was defined based on cytomorphological, histopathological, immunophenotypical, and molecular findings related to the associated with other clonal hematological non-mast cell lineage disease (Figure 1; Table 5).

\section{Prospective Evaluation of the Newly Proposed REMA Algorithm (Validation Group)}

In order to explore the utility of the proposed algorithm, we prospectively applied it in an out-ofsample mode, to another group of 117 cases with 
Table 7 Distribution of mastocytosis patients according to the WHO classification and the new proposed algorithm and refined reclassification

\begin{tabular}{|c|c|c|c|c|}
\hline \multirow[t]{2}{*}{ Subtype of mastocytosis } & \multicolumn{2}{|c|}{ Testing series $(\mathrm{n}=133)$} & \multicolumn{2}{|c|}{ Validation series $(\mathrm{n}=117)^{\mathrm{a}}$} \\
\hline & $\begin{array}{c}\text { WHO } \\
\text { classification } \\
\text { no. of cases (\%) }\end{array}$ & $\begin{array}{c}\text { Proposed } \\
\text { reclassification } \\
\text { no. of cases }(\%)\end{array}$ & $\begin{array}{c}\text { WHO } \\
\text { classification } \\
\text { no. of cases }(\%)\end{array}$ & $\begin{array}{c}\text { Proposed } \\
\text { reclassification } \\
\text { no. of cases (\%) }\end{array}$ \\
\hline Cutaneous mastocytosis & $20(15 \%)$ & $9(7 \%)$ & $1(1 \%)$ & $1(1 \%)$ \\
\hline Indolent systemic mastocytosis & $93(70 \%)$ & $99(74 \%)$ & $60(51 \%)$ & $66(56 \%)$ \\
\hline Indolent systemic mastocytosis with skin lesions & & $82(61 \%)$ & & $45(38 \%)$ \\
\hline Indolent systemic mastocytosis without skin lesions & & $17(13 \%)$ & & $21(18 \%)$ \\
\hline Well-differentiated systemic mastocytosis & NI & $9(7 \%)$ & NI & $1(1 \%)$ \\
\hline $\begin{array}{l}\text { Systemic mastocytosis associated to other } \\
\text { hematological non-mast cell lineage disease }\end{array}$ & $6(5 \%)$ & $6(4.5 \%)$ & $1(1 \%)$ & $1(1 \%)$ \\
\hline Aggressive systemic mastocytosis & $11(8 \%)$ & $8(6 \%)$ & $3(3 \%)$ & 0 \\
\hline Mast cell leukemia & $2(1 \%)$ & $2(1.5 \%)$ & 0 & 0 \\
\hline Unclassifiable cases & $1(1 \%)$ & 0 & $4(3 \%)$ & 0 \\
\hline
\end{tabular}

NI: not included; WHO: World Health Organization.

Results are displayed as number of cases and percentage between brackets.

${ }^{\mathrm{a}}$ Forty-eight cases suspected of having mastocytosis were not diagnosed of mastocytosis with both the REMA and WHO criteria.

suspected diagnosis of mastocytosis who were consecutively referred to the Instituto de Mastocitosis from October 2007 to December 2009. Based on this strategy, $117 / 117$ cases $(100 \%)$ with mastocytosis and clonal mast cell disorders compatible with mastocytosis were correctly classified (Table 7). Compared with the WHO criteria, differences were as follows (1) 4/117 (3\%) patients were unclassifiable by the WHO as they showed only 1 or 2 minor criteria with no major criterion in the absence of mastocytosis in the skin; (2) 3/117 indolent systemic mastocytosis cases according to the REMA's criteria who were classified as aggressive systemic mastocytosis by the WHO, only because they had skeletal lesions but no other ' $\mathrm{C}$ '-findings.

\section{Discussion}

During the past 15 years, major advances have been achieved in both the diagnosis and classification of mastocytosis ${ }^{2-4,12,34}$ with very detailed studies about the cytological, ${ }^{6}$ immunohistochemical, ${ }^{5}$ immunophenotypic, ${ }^{25,33}$ and molecular features of mast cells in mastocytosis. Undoubtedly, the WHO criteria represented a major step forward in both the diagnosis and classification of mastocytosis, contributing to the distinction between good- (eg cutaneous mastocytosis and indolent systemic mastocytosis) vs poor-prognosis subgroups (eg aggressive systemic mastocytosis, mast cell leukemia). However, since the initial proposal, only one study based on 59 patients ${ }^{19}$ has prospectively evaluated the WHO criteria. Interestingly, preliminary data from this study indicate that based on the WHO criteria, some patients suffering from a true systemic mastocytosis cannot be classified as such. In line with these findings, it has been suggested by consensus groups that specific subtypes of masto- cytosis may not fulfill the WHO diagnostic criteria, particularly among well-differentiated systemic mastocytosis and indolent systemic mastocytosis without skin lesions cases. ${ }^{2}$ Additional data also indicate that prediction of outcome among indolent systemic mastocytosis, as well as the distinction between both cutaneous mastocytosis vs systemic mastocytosis and indolent systemic mastocytosis vs aggressive systemic mastocytosis, and between stable vs progressive disease could also benefit from the introduction of further objective criteria. ${ }^{12,18}$ Altogether these observations point out the need for additional refined criteria. ${ }^{19}$

In this study, we retrospectively applied the current WHO criteria to the diagnosis and classification of a group of 133 cases suspected of mastocytosis and a heterogeneous group of 855 controls. Overall, no false-positive cases were found with only one case that could not be classified. However, despite this high diagnostic efficiency, 15 cases could have been more precisely classified. Most of these 15 cases corresponded to well-differentiated systemic mastocytosis and patients with an overall picture similar to indolent systemic mastocytosis, who were classified as either cutaneous mastocytosis or aggressive systemic mastocytosis.

Regarding the individual WHO criterion, presence of dense multifocal bone marrow mast cell infiltrates was highly specific of mastocytosis, since it was not observed in any of the control cases; however, around one fourth of all good-prognosis patients lacked on the major criterion for systemic mastocytosis at the same time they showed normal or slightly increased $(<20 \mathrm{ng} / \mathrm{ml})$ serum baseline tryptase; these findings point out the need for more sensitive diagnostic criteria (eg other minor WHO criteria), in line with previous observations. ${ }^{19}$ In around $80 \%$ of our systemic mastocytosis cases, an abnormal bone marrow mast cell morphology was 
found, typically including an admixture of spindleshaped mast cell and either round or polygonal mast cells. In turn, spindle-shaped fully granulated mast cell in the absence of other aberrant changes were found in $4 \%$ of all bone marrow control samples, mainly among myelodisplastic syndrome. Altogether, these findings support the utility of careful morphological analysis of bone marrow smears for the detection of abnormal bone marrow mast cells in mastocytosis. However, it should be noted that falsenegative results were relatively frequently observed, particularly in well-differentiated systemic mastocytosis where mast cells were round, usually with a clearly increased size, and they were fully granulated with frequent degranulation phenomena making them morphologically rather similar to normal bone marrow mast cells.

Since in the early stages of the disease, indolent systemic mastocytosis patients usually display very low mast cell burden in the absence of bone marrow mast cells aggregates, demonstration of the presence of either clonal or phenotypically aberrant mast cells in the bone marrow and/or other tissues by highly sensitive methods becomes essential. In line with other reports, the presence of CD25 ${ }^{\text {bright }+}$ bone marrow mast cells appeared to be a highly specific diagnostic criteria being found in most systemic mastocytosis patients, ${ }^{19,25,35-39}$ but in only a few control bone marrow samples, all of which corresponded to FIP1L1/PDGFRA + chronic eosinophilic leukemia and myelodisplastic syndrome, in line with previous observations; ${ }^{10}$ altogether these findings support the usage of CD25 expression on bone marrow mast cells as a surrogate marker for mast cells clonality. Noteworthy, the presence of clonal mast cells assessed through KIT mutation or a clonal HUMARA test (in bone marrow mast cells from women lacking KIT mutations) in highly purified mast cells was found in virtually every case (94\%), confirming previous observations; ${ }^{18,27}$ this indicates that KIT mutation in bone marrow mast cells may have a higher diagnostic value than other WHO criteria.

Conversely, serum tryptase $>20 \mathrm{ng} / \mathrm{ml}$ was the less sensitive WHO diagnostic criteria, since it was only found in $\approx 70 \%$ of our cases; in addition, serum tryptase $>20 \mathrm{ng} / \mathrm{ml}$ was also identified among systemic secondary or idiopathic (nonclonal) mast cell-activation syndrome patients, supporting its lower specificity vs other WHO criteria.

Based on these findings, we propose a new objective algorithm for refined diagnosis and classification of mastocytosis, which includes the WHO criteria with the exception of serum tryptase, plus other objective clinical (eg systemic mast cellactivation symptoms and mastocytosis in the skin) and laboratory data (eg $\beta_{2}$-microglobulin and LDH serum levels); this new diagnostic algorithm may be easily applied in the clinical setting to patients suspected of having mastocytosis. Once this new algorithm was designed, it was prospectively evaluated in an independent series of patients, confirming its improved efficiency over the WHO criteria; this was particularly true for the distinction between cutaneous mastocytosis and systemic mastocytosis, specially among well-differentiated systemic mastocytosis and to a lower extent also for indolent systemic mastocytosis without skin lesions.

Once the diagnosis of systemic mastocytosis has been established, further subclassification into specific disease entities is mandatory for adequate prognostic stratification and patient management. Also here, the proposed new algorithm could have an improved efficiency, particularly as regards the combined usage of additional objective criteria (eg serum $\beta_{2}$-microglobulin and LDH levels in addition to 'C'-findings) for the distinction between indolent systemic mastocytosis and aggressive systemic mastocytosis.

If only mastocytosis in the skin is present, diagnosis of cutaneous mastocytosis could be made, while presence of bone marrow mast cell aggregates or CD25 bright+ or mutated/clonal bone marrow mast cell, in addition to mastocytosis in the skin, supports the diagnosis of systemic mastocytosis. Among the later patients, well-differentiated systemic mastocytosis showed unique features: coexistence of skin involvement and compact bone marrow mast cell aggregates with round shape and larger CD25- mast cell; in addition, KIT D816V mutation ${ }^{13}$ or other KIT mutations ${ }^{14}$ were found in only a few well-differentiated systemic mastocytosis cases. Whenever well-differentiated systemic mastocytosis do not show bone marrow mast cell aggregates, failure of the current WHO criteria (but not the new algorithm) would most likely occur. Conversely, indolent systemic mastocytosis without skin lesions and mast cell leukemia were identified because of lack of mastocytosis in the skin in association with anaphylaxis and a relatively low (indolent systemic mastocytosis without skin lesions) or high (mast cell leukemia) mast cell burden. Finally, coexistence of CD25 $5^{\text {bright }+}$ mast cell and compact bone marrow mast cell aggregates, in addition to mastocytosis in the skin and/or the KIT D816V mutation, identified a heterogeneous group of patients including indolent systemic mastocytosis with skin lesions, aggressive systemic mastocytosis, and systemic mastocytosis-associated with other clonal hematological non-mast cell lineage disease. Among them, systemic mastocytosis-associated hematological non-mast cell lineage disease-was easily identifiable on the basis of clinical, cytomorphological, histological, immunophenotypical, and molecular features of the associated with other clonal hematological non-mast cell lineage disease. Conversely, the distinction between indolent systemic mastocytosis and aggressive systemic mastocytosis required additional and more objective parameters on top of 'C'-findings. In this regard, combined assessment of serum 
$\beta_{2}$-microglobulin and LDH appeared to be particularly useful since, with both parameters, some clinically stable aggressive systemic mastocytosis cases as per the WHO, would be reclassified as indolent systemic mastocytosis. Interestingly, these later cases showed severe osteoporosis with pathological fractures as the only C-finding; in line with our previous observations, ${ }^{18}$ neither severe osteoporosis nor pathological fractures secondary to osteoporosis should be included as a 'C'-finding, except in cases with demonstrated mast cell infiltration in lesional areas. If this holds true, these 3/11 cases who had aggressive systemic mastocytosis according to the WHO, would be reclassified as indolent systemic mastocytosis by the new algorithm here proposed with strong implications in patients' prognosis and life expectancy. Noteworthy, none of the other aggressive systemic mastocytosis patients showed pathological fractures.

In summary, here we confirm the robustness of the WHO criteria for the diagnosis and classification of mastocytosis but provide evidence for the need of additional refinement of the WHO system with the potential introduction of the proposed new parameters and algorithm, which are particularly useful for the diagnosis of well-differentiated systemic mastocytosis, patients at early stages of the disease (eg indolent systemic mastocytosis without skin lesions) and discrimination between indolent systemic mastocytosis and aggressive systemic mastocytosis.

\section{Acknowledgements}

This work was supported by grants from the Fondo de Investigaciones Sanitarias (FIS) of the Ministerio de Ciencia e Innovación of Spain (PS09/00032 and RETICS RD06/0020/0035-FEDER); Junta de Comunidades de Castilla La Mancha (FISCAM 2007/36, FISCAM 2008/46). Junta de Castilla y León (Grant SAN1778/2009 and GR37); ACG-M is supported by a grant from FIS/FEDER (CP03/00035); CT was supported by a grant from the Fundação para a Ciência e Tecnologia (FCT) of Portugal (SFRH/BD/ 17545/2004) and by a grant from the Fondo de Investigaciones Sanitarias (FIS) of the Ministerio de Ciencia e Innovación of Spain (PI08/90881).

\section{Disclosure/conflict of interest}

The authors declare no conflict of interest.

\section{References}

1 Metcalfe DD. Clinical advances in mastocytosis: an interdisciplinary roundtable discussion. J Invest Dermatol 1991;96(Suppl):1S-65S.

2 Valent P, Horny HP, Escribano L, et al. Diagnostic criteria and classification of mastocytosis: a consensus proposal. Leuk Res 2001;25:603-625.
3 Valent P, Horny HP, Li CY, et al. Mastocytosis (mast cell disease). In: Jaffe ES, Harris NL, Stein H, Vardiman JW (eds). World Health Organization (WHO) Classification of Tumours. Pathology \& Genetics. Tumours of Haematopoietic and Lymphoid Tissues. IARC Press: Lyon, France, 2001, pp 291-302.

4 Horny HP, Metcalfe DD, Bennet JM, et al. Mastocytosis. In: Swerdlow SH, Campo E, Harris NL, Jaffe ES, Pileri SA, Stein H, Thiele J, Vardiman JW (eds). WHO Classification of Tumours of Haematopoietic and Lymphoid Tissues, 4th edn. IARC: Lyon, 2008, pp 54-63.

5 Horny HP, Sillaber C, Menke D, et al. Diagnostic value of immunostaining for tryptase in patients with mastocytosis. Am J Surg Pathol 1998;22: 1132-1140.

6 Sperr W, Escribano L, Jordan JH, et al. Morphologic properties of neoplastic mast cells: delineation of stages of maturation and implication for cytological grading of mastocytosis. Leuk Res 2001;25:529-536.

7 Sperr WR, Jordan JH, Baghestanian M, et al. Expression of mast cell tryptase by myeloblasts in a group of patients with acute myeloid leukemia. Blood 2001;98:2200-2209.

8 Sperr WR, Jordan JH, Fiegl M, et al. Serum tryptase levels in patients with mastocytosis: correlation with mast cell burden and implication for defining the category of disease. Int Arch Allergy Immunol 2002;128:136-141.

9 Sperr WR, Stehberger B, Wimazal F, et al. Serum tryptase measurements in patients with myelodysplastic syndromes. Leuk Lymphoma 2002;43:1097-1105.

10 Klion AD, Noel P, Akin C, et al. Elevated serum tryptase levels identify a subset of patients with a myeloproliferative variant of idiopathic hypereosinophilic syndrome associated with tissue fibrosis, poor prognosis, and imatinib responsiveness. Blood 2003;101:4660-4666.

11 Escribano L, Diaz-Agustin B, López A, et al. Immunophenotypic analysis of mast cells in mastocytosis: when and how to do it. Proposals of the Spanish network on mastocytosis (REMA). Cytometry 2004; 58B:1-8.

12 Valent P, Akin C, Escribano L, et al. Standards and standardization in mastocytosis: consensus statements on diagnostics, treatment recommendations and response criteria. Eur J Clin Invest 2007;37:435-453.

13 Akin C, Fumo G, Yavuz AS, et al. A novel form of mastocytosis associated with a transmembrane c-kit mutation and response to imatinib. Blood 2004;103: 3222-3225.

14 Akin C, Escribano L, Núñez R, et al. Well-differentiated systemic mastocytosis: a new disease variant with mature mast cell phenotype and lack of codon 816 c-kit mutations [abstract]. J Allergy Clin Immunol 2004;113:S327.

15 Sonneck K, Florian S, Mullauer L, et al. Diagnostic and subdiagnostic accumulation of mast cells in the bone marrow of patients with anaphylaxis: monoclonal mast cell activation syndrome. Int Arch Allergy Immunol 2006;142:158-164.

16 Alvarez-Twose I, Gonzalez de OD, Sanchez-Munoz L, et al. Clinical, biological and molecular characteristics of mast cell activation disorders: a prospective study in 62 patients by the Spanish network on mastocytosis (REMA) [abstract]. J Allergy Clin Immunol 2009; 123:S141. 
17 Bonadonna P, Perbellini O, Passalacqua G, et al. Clonal mast cell disorders in patients with systemic reactions to Hymenoptera stings and increased serum tryptase levels. J Allergy Clin Immunol 2009;123:680-686.

18 Escribano L, Avarez-Twose I, Sanchez-Munoz L, et al. Prognosis in adult indolent systemic mastocytosis: a long-term study of the Spanish network on mastocytosis in a series of 145 patients. J Allergy Clin Immunol 2009;124:514-521.

19 Johnson MR, Verstovsek S, Jorgensen JL, et al. Utility of the World Heath Organization classification criteria for the diagnosis of systemic mastocytosis in bone marrow. Mod Pathol 2009;22:50-57.

20 Kanis JA. Assessment of fracture risk and its application to screening for postmenopausal osteoporosis: synopsis of a WHO report. WHO Study Group. Osteoporos Int 1994;4:368-381.

21 Miller PD. Guidelines for the diagnosis of osteoporosis: T-scores vs fractures. Rev Endocr Metab Disord 2006;7:75-89.

22 Horny HP, Valent P. Diagnosis of mastocytosis: general histopathological aspects, morphological criteria, and immunohistochemical findings. Leuk Res 2001;25: $543-551$.

23 Li CY. Diagnosis of mastocytosis: value of cytochemistry and immunohistochemistry. Leuk Res 2001;25: 537-541.

24 Orfao A, Escribano L, Villarrubia J, et al. Flow cytometric analysis of mast cells from normal and pathological human bone marrow samples. Identification and enumeration. Am J Pathol 1996;149:1493-1499.

25 Escribano L, Orfao A, Diaz-Agustin B, et al. Indolent systemic mast cell disease in adults: immunophenotypic characterization of bone marrow mast cells and its diagnostic implications. Blood 1998;91:2731-2736.

26 Sotlar K, Fridrich C, Mall A, et al. Detection of c-kit point mutation Asp-816 $\rightarrow$ Val in microdissected pooled single mast cells and leukemic cells in a patient with systemic mastocytosis and concomitant chronic myelomonocytic leukemia. Leuk Res 2002;26: 979-984.

27 Garcia-Montero AC, Jara-Acevedo M, Teodosio C, et al. KIT mutation in mast cells and other bone marrow haematopoietic cell lineages in systemic mast cell disorders. A prospective study of the Spanish network on mastocytosis (REMA) in a series of 113 patients. Blood 2006;108:2366-2372.

28 Escribano L, Orfao A, Villarrubia J, et al. Sequential immunophenotypic analysis of mast cells in a case of systemic mast cell disease evolving to a mast cell leukemia. Cytometry 1997;30:98-102.
29 Escribano L, Navalón R, Núñez R, et al. Flow cytometry immunophenotypic analysis of human mast cells. In: Robinson JP, Darzynkiewicz Z, Dean P, Orfao A, Rabinovitch P, Wheeless L (eds). Current Protocols in Cytometry. John Wiley \& Sons: New York, 2000, pp 6.6.1-6.6.18.

30 Sotlar K, Escribano L, Landt O, et al. One-step detection of c-kit point mutations using PNA-mediated PCR-clamping and hybridization probes. Am J Pathol 2003;162:737-746.

$31 \mathrm{Wu}$ Y, Basir Z, Kajdacsy-Balla A, et al. Resolution of clonal origins for endometriotic lesions using laser capture microdissection and the human androgen receptor (HUMARA) assay. Fertil Steril 2003;79 (Suppl 1):710-717.

32 Horny HP, Sotlar K, Stellmacher F, et al. The tryptase positive compact round cell infiltrate of the bone marrow (TROCI-BM): a novel histopathological finding requiring the application of lineage specific markers. J Clin Pathol 2006;59:298-302.

33 Teodosio C, Garcia-Montero AC, Jara-Acevedo M, et al. Mast cells from different molecular and prognostic subtypes of systemic mastocytosis display distinct immunophenotypes. J Allergy Clin Immunol 2010;125: 719-726.

34 Valent P, Escribano L, Parwaresch RM, et al. Recent advances in mastocytosis research-summary of the Vienna Mastocytosis Meeting 1998. Int Arch Allergy Immunol 1999;120:1-7.

35 Bodni RA, Sapia S, Galeano A, et al. Indolent systemic mast cell disease: immunophenotypic characterization of bone marrow mast cells by flow cytometry. J Eur Acad Dermatol Venereol 2003;17:160-166.

36 Pardanani A, Kimlinger $\mathrm{T}$, Reeder $\mathrm{T}$, et al. Bone marrow mast cell immunophenotyping in adults with mast cell disease: a prospective study of 33 patients. Leuk Res 2004;28:777-783.

37 Sotlar K, Horny HP, Simonitsch I, et al. CD25 indicates the neoplastic phenotype of mast cells-a novel immunohistochemical marker for the diagnosis of systemic mastocytosis (SM) in routinely processed bone marrow biopsy specimens. Am J Surg Pathol 2004;28:1319-1325.

38 Bohm A, Fodinger M, Wimazal F, et al. Eosinophilia in systemic mastocytosis: clinical and molecular correlates and prognostic significance. J Allergy Clin Immunol 2007;120:192-199.

39 Lim KH, Tefferi A, Lasho TL, et al. Systemic mastocytosis in 342 consecutive adults: survival studies and prognostic factors. Blood 2009;113: 5727-5736. 